\title{
Social Identity Construction of Mangrove Forest Ecotourism
}

\section{(Study on Mangrove Forest Ecotourism in Lubuk Kertang Village, Sub-District of West Brandan, District of Langkat)}

\author{
Anismar $^{1}$ \\ ${ }^{1}$ Lecturer of Communication Science of Malikussaleh University and Doctorate Degree student of UMT \\ * Corresponding author: anismar@unimal.ac.id
}

\begin{abstract}
This study aimed to identify the construction of social identity of Mangrove Forest Ecotourism (A study on mangrove forest ecotourism in Lubuk Kertang Village, Sub-District of West Brandan, District of Langkat). Mangrove Forest Ecotourism in the region is one of the existing ecotourism destinations for mangrove forests. This study focused in determining the process of social identity construction in a consumptive culture within the tourists' community at Mangrove Forest Ecotourism in Lubuk Kertang Village, Sub-District of West Brandan, District of Langkat during their visit. This research uses Social Construction Theory by Peter L. Berger and Thomas Luckmann with a descriptive qualitative approach. The informants of this study were domestic tourists who had consumptive values and visited mangrove forest ecotourism on weekends. Data collection techniques in this study were obtained through interviews, observation and documentation. This study was only limited to the construction process carried out by tourists with data obtained from interviews. The study concluded that ecotourism of the Mangrove Forest in Lubuk Kertang Village had not become a tourist area or a stimulant that shaped and built a new reality as a pseudo reality. Neither was it been able to form the image of the tourist destination itself. So far, the visit relied heavily on social media and the kinship system.
\end{abstract}

Keywords: Social identity construction, Mangrove Forest Ecotourism, Tourists, Consumptive Culture, Fashion

\section{INTRODUCTION}

Mangrove forest is one of the biological resources that are located on the coast. According to Law Number 41 of 1999 concerning on the forestry, article 1 paragraph 2, mangrove forests are one of the unique and vulnerable coastal ecosystems due to their position as a transitional ecosystem between terrestrial and marine ecosystems. This forest is said to be very fertile because all parts of the mangrove vegetation are a source of food for life in the mangrove ecosystem which is a habitat for various species of birds, mammals, reptiles, and other types of biota. This resulted in high biota diversity, and functions as one of the life support systems for sea ecosystems.

Lubuk Kertang Village, Sub-District of West Brandan, District of Langkat in North Sumatra Province is host of the largest Mangrove Forest in Indonesia with an area of $638.47 \mathrm{Ha}$. Of this vast area, around 430 hectares of mangrove forests is in good conditions, meanwhile the remaining 200 hectares need more attention. The Mangrove Forest in Lubuk Kertang Village is managed by nine groups. Each has its own specific target and responsibilities. One of the groups, Mekar group, for instances, is responsible for managing ecotourism sites, planting and guarding the mangrove of 80 hectares with an active status.

Apart from its beautiful natural scenery, Mangrove Forest ecotourism in Lubuk Kertang Village is also one of the very unique natural tourism areas. This is because this ecosystem is in the estuary area. This area has a unique and distinctive appeal to the plants and animals that live there.

Being the centre of attraction, mangrove forest is a natural ecotourism destination. It is due to its geographical entities as the main the elements of attraction and purposes of visit. Facilities and related 
access are built surrounding the site to attract the communities coming in and visiting the site. According to Ali Hasan (2015), the attractiveness of tourist destinations is the main motivation for tourists to make visits. This is also true to ecotourism site where its natural beauty becomes source of the attraction. Visits are therefore highly dependent on attractions, amenities and accessibility.

An effort to utilize local natural resources in Lubuk Kertang Village carried out by the blooming group as mangrove forest managers. Teams then developed natural tourism with the concept of ecotourism. In addition to being an area with natural beauty, other efforts were also made to protect and preserve mangrove forests by conducting conservation efforts. This was done by mangrove forest managers because they overviewed the large opportunities generated by the large number of tourists visiting by creating a tourist attraction that is in accordance with the culture of the majority of today's society.

Social media had also played significant role in promoting and developing the region. Media communication can also construct social identity by communicating via social media accounts such as WhatsApp, Instagram, YouTube, and many more as platform of promotion by posting photos or videos while traveling and wearing local clothes. Accessories utilizing and promoting area to inform the public in order to obtain recognition of the individual's existence that he is traveling and possesses a luxury item. This has a correlation with the majority of people who are consumptive of the use and development of social media in building social identity in a consumptive culture in the eyes of the public.

\section{LITERATURE REVIEW}

Agus Ganjar Runtiko (2009) in "Construction of Social Identity of Marginalized Youth" (A Case Study among Teenagers of Street Singers in Purwokerto) looked at the phenomenon of street teenager street singers. Often, they were judged as a social disease without first looking at the root cause of that action. However, teenage street singers are part of the nation's generation to whom the government and other social institutions are responsible for preparing them so they don't become a generation without a future. Departing from this phenomenon, a study was conducted to understand in depth how these teenage buskers construct their social identity.

I Nyoman Urbanus and Febianti (2017) explained in their study entitled "Analysis of the impact of tourism development on consumer behavior in the South Bali region". The research examined the analysis of the impact of tourism development on the consumptive behavior of the people of the South Bali region which affects industrial development in the era of globalization which makes the supply of goods in the tourism area abundant. That way people will easily be attracted to consumer goods due to abundant options before their eyes. The habits and lifestyles of the people change in a relatively short time leading to a luxurious life and tend to be excessive, which in turn leads to a consumptive lifestyle.

Furthermore, Saifuddin (2018) elaborated in his research entitled "Construction of Social Identity Against Five Beggars in Lhokseumawe City". This research was motivated by the original identity as an ordinary person who constructs his identity as a beggar due to economic factors and physical deficiencies so that he cannot work like normal people. They sought for people's sympathy and dressed up like beggars. In fact, many were driven by a promising income, rather than having to work in formal and non-formal occupations. In addition, this profession is considered relatively easy and required little acting work. The purpose of this study was to determine the construction carried out by five beggars in Lhokseumawe City.

\section{RESEARCH METHODOLOGY}

The method used in this research was a qualitative research method with a descriptive approach. Qualitative research methods were methods that collected, processed, interpreted and tried to understand the meaning of an event of human behavior interaction in certain situations so that it can provide a systematic picture (Kriyantono, 2007: 58).

Qualitative data took a descriptive approach in the form of spoken words or descriptions where the data was obtained from interviews, documentation and observations of the behavior of the object under 
study. It has always been used by researchers so that researchers do not see that something is the way it is (Moleong, 2016: 11).

\subsection{Research Informants}

Research informants are research subjects who can provide information or data related to the problem and focus of the research being studied. The informants in this study were selected using purposive sampling technique, namely the technique of taking data source informants with certain considerations. Research informants include people who are selected on the basis of certain criteria and considerations that have been determined based on the research objectives (Kriyantono, 2007: 155). Some of the informants' criteria are:

1. Tourists visiting Lubuk KertangVillage Mangrove Forest Ecotourism on weekends (Friday, Saturday and Sunday).

2. Domestic tourists (tourists who travel to other places, but are still in their own country).

3. Tourists who are limited to their consumptive values.

\section{RESULT AND DISCUSSION}

The results obtained in this study show that Ecotourism of the Mangrove Forest in Lubuk Kertang Village had not been able to become a tourist area or a stimulant in shaping and building a new reality as a pseudo reality, nor had it been able to establish an image of the tourist attraction itself. So far, tourist coming to the sites were returning tourist or those receiving feedbacks from their relatives and close friends only.

Social reality can be constructed through a dialectical process that occurs with three simultaneous moments, namely at the same time in externalizing its own existence into the sociocultural world and internalizing its existence as an objective reality through externalization, objectivation and internalization.

Externalization is a process of adjustment to the environment. This adjustment is in the form of outpouring and self-expression into the world, both in the form of mental and physical activities. Man, of course, always devotes himself to the place where he is. The externalization process in this study is shown by the views of tourists about the importance of traveling and the importance of paying attention to the clothes worn when traveling. Where the views of tourists who become informants in this study mostly state that they need inner pleasure, the need for health by seeking pleasure, breadth, satisfaction and entertainment for themselves in one way, namely refreshing to a tourism place.

However, behind this statement, several informants revealed that they carried out tourism activities due to adjusting / adapting to the surrounding environment from what they had seen and knew. Externalization becomes the initial process of forming social construction. The most basic externalization process is how individuals or subjects with their agency abilities adapt to the texts of life, such as what tourists do when they see something new and something they have never known at all from the outside world which is used as an experience. This experience can be in the form of something like an external culture that is applied by some domestic tourists to become a habit that is often done when carrying out tourism activities, this can be said as tourists who adhere to a consumptive culture.

The social identity construction process plays an important role in the imperative of mangrove forest ecotourism tourists to act in order to create a pseudo reality according to their respective goals, because the pseudo reality created by the construction process occurs because it is influenced by several factors such as the influence of closest friends. Then there is a process that creates a pseudo reality that is different from the real reality.

Actions taken in the social identity construction process for tourists in the consumptive culture above certainly give birth to a pseudo reality in which this process can occur because tourists get information from other people, mass media advertisements, the internet, or even from various forms of information which are obtained directly.

Internal factors such as age, occupation, economic conditions, personality, gender can also be factors driving tourists to construct social identities. The social identity construction process carried out by tourists can be seen from the personality, occupation and economic conditions that have become more consumptive with the desire to be able to buy and 
own goods or food that are no longer used as basic necessities.

As a natural tourist destination, the Ecotourism of the Mangrove Forest in Lubuk Kertang Village has available shopping facilities for goods / souvenirs made from purun plants which are still managed by the local community and the managers of the tourist attractions themselves as well as selling food such as chips made from jeruju leaves or holly mangroves namely, shrubs that can be processed into various foods such as chips and jeruju tea, which contain many benefits.

The construction of identity in terms of consumptive ideology in mangrove forest ecotourism tourists, in addition to providing pleasure and eliminating the boundaries of the needs of the value of an item, which is also a representation of the existence of an individual for a specific purpose. Tourists not only want to have fun but tourists also try to construct their social identity in increasing their existence which will eventually get recognition from their social environment.

High interaction in the social environment and social media has an impact on the high level of information that develops, so that many people are competing to display information for certain needs, both in the form of self-actualization, self-existence, business, and information seeking. The social environment such as at work, school, campus, residence and social media such as Instagram, YouTube and so on causes the logic and mindset of humans in consuming, this is because of the active motivation of individuals to consume something they want. This makes an individual able to know developments about the latest information, goods and lifestyle and will encourage someone to consume something they see for their own needs, satisfaction and pleasure. Gaining prestige from others is a form of consumptive culture.

The construction of social identity in a consumptive culture is certainly inseparable from everyday lifestyle factors such as the problem of dressing as an identity which is a form of social dialectic in articulating reality. Clothing conveys the mission and message to others and is an image to emphasize various social functions in social transformation. In addition, one of the functions of clothing is to state social status and standardize norms through its use. For the context of a multiculturalist society like Indonesia, the use of clothing is very helpful in identifying one's origins, tastes, and work. The development of society in identifying fashion as an identity construction includes traditional, modern and post-modern societies.

The construction of social identity in terms of appearance through clothing ranging from everything worn from head to toe is one of the most dominant aspects in tourists' efforts to construct their social identity in a consumptive culture when traveling to get pleasure, satisfaction, and self-image (self-image) that the tourist wants to build.

\section{CONCLUSION}

Based on the results, the researcher is able to draw a conclusion that Mangrove Forest Ecotourism in Lubuk Kertang Village is not a place where the identity formation occurs since the identity has been constructed from outside before the tourists visited the place. The outside reality such as social media and the kinship system is capable of allowing the identity construction process happens.

It can be concluded that the results obtained in this study show that Ecotourism of the Mangrove Forest in Lubuk Kertang Village has not been able to become a tourist area or a stimulant in forming and building a new reality as a pseudo reality and has not been able to form the image of the tourist itself, because the image of tourists has been formed before they visited the place.

\section{REFERENCES}

Hasan, Ali. 2018. StudiDayaTarikWisataAlamHutan Mangrove PantaiBarosBantul, Hutan Mangrove PantaiPasirKadilangu,Hutan Mangrove JembatanApi apiTemondanKinerjaBisnisPariwiata. Jurnal Media Wisata, Vol.16 (2).

Kriyantono, Rachmat. 2007. TeknikPraktisRisetKomunikasi: DisertaiContohPraktisRiset Media, Advertising, KomunikasiOrganisasi, KomunikasiPemasaran, Public Relations. Jakarta: Kencana. 
Moleong, Lexy. J. 2016.

MetodologiPenelitianKualitatif. Bandung: PT

RemajaRosdakarya.

Runtiko, Agus G. 2009.

KonstruksiIdentitasSosialKaumRemajaMarjinal(Stud iKasusKalanganRemajaPengamenJalanandiPurwoke to). JurnalPenelitianKomunikasi, Vol.12 (1).

Undang-UndangNomor 41 Tahun 1999

Pendit, Nyoman S. 2003.

IlmuPariwisata:SebuahPengantarPerdana. Jakarta: PradnyaParamita. 